\title{
Домінанти і перспективи постмодерної літератури і теоретичного її осмислення
}

\author{
Михайло Наєнко (Kyjev)
}

\begin{abstract}
Анотація
У статті розглядається теорія та практика постмодерної літератури з акцентом на необхідності теоретичного розуміння ії художньої вартості. Розглядаючи погляди філософів та історію літературних стилів (бароко, романтизм, реалізм, символізм тощо), автор вважає, що постмодерністська поетика вичерпала себе. Постмодернізм створив явища з виразними національними особливостями, що знайшло своє відображення в латиноамериканському магічному реализмі, європейському неоміфологізмі та химерній прозі, а також у творах українського «старшого» покоління, авторів-шістдесятників та пост-шістдесятників. Спроби молодших поколінь перетворилися на графоманію чи так звану «масову» літературу, що призвело до інфляції істини, краси, добра у змісті творів. Письменники вдавалися до «нового історизму» чи «метамодернізму».
\end{abstract}

\section{Ключові слова}

літературний процес; теорія; художні стилі; постмодерн; поетика; літературні жанри; національна специфіка; моральні чинники; новий історизм

\section{Abstract \\ Dominant Features and Perspectives of Postmodern Literature and Its Theoretical Comprehension}

The article deals with the theory and practice of postmodern literature with an emphasis on the need for a theoretical understanding of its literature artistic merit. The author, with consideration of philosophers' views, and the history of literary styles (Baroque, Romanticism, Realism, Symbolism, etc.), believes that postmodern poetics has exhausted itself. Postmodernism made the phenomena with distinct national features which were reflected in Latin American Magical Realism, European neo-mythologist, and chimerical prose, including the works of Ukrainian "senior" authors, as well as the Sixties, and the Post-Sixties authors. Attempts of the younger generations transformed into graphomania or so-called mass literature leading to the inflation of truth, beauty, and good in the content of works. Writers resorted to the „new historicism" or „metamodernism“.

\section{Key words}

literary process; theory; artistic styles; postmodernism; poetics; literary genres; national specificity; moral factors; new historicism 
В літературі, як і мистецтві загалом, головна константа - художній твір. Але без опертя на теорію творчості уявлення про той твір завжди буде не повним чи й хибним, що вестиме процес творення художніх цінностей у прірву цілковитої графоманії. I бути (для творців таких «цінностей») переконаним, що так і треба, що твориться справді мистецтво, бо ж, мовляв, його (графоманію, тобто) читають, купують, популяризують. Небезпечність такої ситуації в тому, що тут «задіяний» (м'яко кажучи) дуже посередній за освітньою підготовкою рецептор (читач) і що таке уявлення про літературу формує посереднє людство, посереднє суспільство. Бо, як не крути, вони (і суспільство, і людство) виховуються таки літературою, тобто - словом.

Прикладів «розгулу графоманії» без опертя на серйозну теорію в нашій літературі безліч. Починаючи, мабуть, із античних віршів у формі глека, із середньовічного «плетіння словес», згодом - барокових паліндромів, просвітянської «котляревщини» та епігонів Шевченка і кінчаючи соцреалістичними виробничими повістями й романами на зразок «Золототисячника» I. Рябокляча, «Лихобора» В. Собка чи сучасного продукування деяких постмодерних «залепух» (як сказав би І. Франко). 3'ява їх зумовлена, звичайно, відсутністю природного таланту в авторів, але й цілковитою безграмотністю їх у галузі літературної теорії. Поняття «теорія», як знаємо, дуже широке i, щоб трохи звузитись, спинюсь на такому складнику її, як художній стиль. Він у кожного справжнього письменника справді свій, хоча й пов'язаний із ширшим уявленням про нього: стиль літературного напряму, часу, стиль епохи.

Означення і навіть назви літературних стилів (напрямів) з'являються переважно після завершення їхнього функціонування. Інколи для цього потрібні роки, десятиліття і навіть століття. Ранні форми реалізму, наприклад, називали спочатку «істинним романтизмом» (О. Пушкін), і лише згодом цей термін став набувати, умовно кажучи, суто свого обличчя. Воно формувалося в деяких міркуваннях самих письменників, зокрема, Оноре де Бальзака ${ }^{1}$, а ввійшло в теоретичний побут у 50-х роках XIX ст., коли французький літературний критик Жуль Шанфлері запропонував такий термін («реалізм») для позначення мистецтва, що протистоїть романтизму і академізму. Термін «бароко» можна вважати рекордсменом у своєму народженні й утвердженні. Пологи його тривали років двісті. Адже барокова творчість припинила своє існування в третій чверті XVIII століття, а таке ім'я йому (стосовно літератури) дали тільки в ХХ столітті. Саме тоді заговорили, що до барокових творів слід зараховувати творчість білоруса Симеона Полоцького, українця Феофана Прокоповича й ін. Росія цей стиль фактично проспала, а його окремі залишки можна побачити хіба що в дуже раннього Михайла Ломоносова, тобто - в середині XVIII ст., коли вже сходив з літературної арени стиль бароко і зароджувався класицизм.

1 GILENSON, B. A.: Manifesty literaturnyje // Literaturnaja ènciklopedija terminov i ponjatij. Moskva: RAN, 2001, s. 497. 
3 назвою стилю «постмодернізм» справа загалом заплутана. Вважається, що ї̈ вперше вжито ще в 1914 році у праці німецького філософа Рудольфа Панвіца «Криза європейської культури»; через 20 років цей термін з'явився в іспанського літературознавця Федеріко де Оніса, який вживав його (за свідченням деяких дослідників) на позначення періоду в розвитку літератури між модернізмом (18961905) та ультрамодернізмом (1914-1932). Та значного поширення цей термін набув тільки наприкінці 1960-х років спершу для означення стильових тенденцій в архітектурі, спрямованих проти безликої стандартизації в будівництві, а потім і в літературі, живопису та музиці.

Протягом останніх років стали публікуватися роботи з припущенням, що постмодернізм як стиль вичерпав себе. Філософ Сергій Дацюк улітку 2012 року опублікував книгу (а потім і виступив з доповіддю перед фахівцями) з назвою «Загибель постмодернізму». Філософ акцентує, що постмодернізм його таки «дістав». Аналізуючи і книгу, й доповідь Сергія Дацюка, Ольга Михайлова скомпонувала рецензію на них і назвала її висловлюваннями самого С. Дацюка: «Загибель постмодернізму: інфлячія істини, краси і добра».2

Які ж основні претензії до постмодернізму? Насамперед, вважають філософи, у нього немає сутнісного означення. Як, скажімо, в бароко (примхливість у зображенні), романтизму (жадання ідеалу й гіперболізм у мисленні) чи реалізму (відтворення буття у формах «тут-тепер»). Постмодернізм означає лише те, що настало «після модернізму». Ащо ж тоді настало насправді? I як його точно назвати?

Дехто схиляється до думки, що істинний постмодернізм народився з травми Другої світової війни. Ось чому кінець власне модернізму дехто пов'язує зі смертю двох найбільших «модерністів», які спричинили ту війну: Гітлера і Сталіна (відповідно 1945, 1952 рр.). Чому їх називають модерністами?

Тому, що модернізм виріс на увазі до особи, індивіда. На відміну від свого попередника- реалізму, який сповідував «колективну особу», модернізм зорієнтований був на особистість, унаслідок чого народилася велика література і «пізнішого» Франка («Зів'яле листя», «Мойсей», «Пророк» та ін.), і зрілих Ольги Кобилянської («Меланхолійний валь», «Землл», «У неділю рано...»), Лесі Українки («Одержима» $\check{u}$ «Лісова пісня»), Василя Стефаника й Михайла Коцюбинського з їхніми «Новинами», «Синами», «Тінями забутих предків» та «Інтермещио»). Увага до індивідуального породила і хворобливу форму його - егоїзм, егоцентризм. Егоїстичні (егоцентричні) персонажі зустрічалися, як знаємо, у Володимира Винниченка (зневірений інтелігент «кирпатий Мефістофель»), Валер'яна Підмогильного (Радчук у «Місті») та ін.

Вважається, що у власне житті егоцентризм найбільш властивий дітям 8-10-тирічного віку. Вони не здатні зважати на думку когось іншого, а свою особисту вважають єдино правильною. Гітлер і Сталін зупинилися саме на цій стадії дитячого розвитку і тому впевнились у переконанні, що на думку когось іншого можна не зважати, а їхню власну думку можна реалізувати $з$ допомогою зброї.

2 https://hvylya.net/analytics/zakat-postmodernizma-inflyatsiya-istinyi-krasotyi-i-dobra.html 
I розв'язалася Друга світова, яка забрала до 80 мільйонів людських життів. А, може, й усі 100. Після смерті ідеологів такого розуміння ідеалу людської цивілізації почався період, який умовно й назвали постмодернізмом. Він (постмодернізм) повстав проти авторитетів не тільки модернізму, а й його попередників - романтиків та реалістів. У літературі це виявлялося у формі нігілістичного ставлення до давніших і новіших класиків, цитати з них вони використовували для «скидання з корабля сучасності» найвідоміших літературних постатей, зрештою - для іронічного бачення світу як такого. В літературознавче повсякдення при цьому входять запропоновані Роланом Бартом поняття «смерть автора» і навіть (як іронізували його критики) «смерть читача», фетишизуються як виражальні засоби творчості принципи гри, симуляції, фрагментарності тощо. У наслідку почалися (та й досі тривають) наскоки на романтика Т. Шевченка й радянських неоромантиків П.Тичину, О. Довженка чи О. Гончара.

Якщо модернізм фіксував у світі хаос, то постмодернізм помітив наближення цивілізаційного апокаліпсису. Того апокаліпсису, передбачення якого пов'язують 3 біблійним Іваном Богословом і його «Одкровенням». Вияви апокаліпсису в літературі, проте, були не однотипними. Тому розрізняють дуже не схожі між собою національні постмодернізми. Неоднаковим він був у літературі Латинської Америки («Сто літ самотності» Гарсіа Маркеса), у серба Мілорада Павича з його «Хозарським словником», в українців Василя Земляка («Лебедина зграя») чи Василя Стуса ( «Горить сосна - од низу до гори»). Василь Земляк і Василь Стус часом трималися берега модернізму і навіть романтичного народництва, а молодші їхні послідовники (Василь Шкляр із його «Чорним Вороном», Оксана Забужко з їі «Музеєм покинутих секретів», Юрій Андрухович із його «Московіадою», Василь Кожелянко 3 «Конотопом» чи Ліна Костенко 3 «Записками украйнського самашедчого») уже робили крок у відході від постмодернізму та наближенні до запропонованого французами й американцями стилю з назвою новий історицизм, який дехто іменує ще метамодернізмом.

Руйнування постмодернізму відбувається не без крайнощів. Нещодавно Лідія Ільків запропонувала своєрідну мозаїку із творів 88-ми авторів і вийшла в неї нібито власна «сюїта» з 28-ми строф, яку Петро Шкраб'юк назвав «практично постмодерним експериментом». ${ }^{3}$ Ось кілька рядків такого експерименту:

Титани начї - України призначення,

Де мова - спадщина тисячоліть.

Ми не маємо сил для страчення.

Калинове серие над світом горитъ...

Усе це не авторські слова, а вислови, взяті з чужих текстів.

Подібні експерименти стають дедалі рідшими, чи, можливо, й одиничними, зате вагомості набуває таки отой новий історицизм, який іде на зміну постмо-

3 Gazeta «Slovo prosviti», 2019, 4 grudnja. 
дернізму і про який в американо-європейському літературознавстві заговорили порівняно недавно. Із ним там пов'язують такі імена, як С. Грінблатт чи Л. Монроуз, а в Україні до них наближаються, думаю, «Солодка Даруся» Марії Матіос, «Німиі в городi» Лесі Степовички, «Трьохсотлітня Голгофа. Фавор» Катерини Мотрич або подібні. За всіх вад (у тому числі й коректурних) це таки література нового історицизму, в якій зустрічаємо прийоми «перепрочитання» раніш нібито відомого в історії, «одивнення» його, як у колишньому формалізмі, подання тексту в дуже концентрованих формах. Бо що таке «триста літ», які Катерина Мотрич спробувала вбгати в не дуже просторий роман? Що таке «німці в городі», як не одивнення факту, відомого з часу Другої світової, що таке «солодка» Даруся, якщо вона в житті німа і якась (за спостереженням сусідів) ніби несповна розуму? Для сприйняття літератури з такими персонажами потрібна певна інтелектуальна підготовка, потрібне елітарне сприйняття й осмислення художнього світу як такого. Наголошую на цьому через те, що паралельно з такою літературою (її прийнято називати елітарною) набула поширення і література масова, твори якої, на думку дослідників, передбачають дещо спрощене, «комфортне» в лапках читання. В цей ряд літератури можна зарахувати творчість Софії Андрухович («Съомга», «Фелікс Австрія»), Марини Гримич («Клавка») і подібні. Автори цих творів у своєму письмі орієнтуються на розмовну, а не образну, мову, на експлуатації ненормативної лексики тощо. Масова література - явище порівняно нове. У часи ренесансу, бароко й романтизму її, мабуть, не було, а якщо й була - то в обмеженому вигляді (дивись збірник барокової поезії «Аполонова лютня»). Активніше розвинулася вона чи не в роки пізнього романтизму ( Мертве озеро» М. Некрасова й А. Панаєвої), так само - пізнього реалізму (російська белетристика Ігнатія Потапенка й Петра Боборикіна), а в українській літературі - так звані народницькі твори деяких авторів рубежу XIX-XX століть.

Постмодернізм стимулював ще й таке явище в літературі (та особливо - літературознавстві), як плагіат. Почалося все, либонь, із запозичення літераторами цитат з існуючих творів, які вмонтовувалися у власні їхні саморобки, аж поки не почалося «вмонтовування» в них цілих абзаців, сторінок і концепцій. Дехто при цьому керувався суто дитячим принципом: «Цяця-цяця - та в карман». Тобто, маємо в літературі й літературознавстві звичайну дитячу крадіжку. Ї̈̈ концепт набув найбільшого поширення чи не в дисертаційних роботах. Стимуляторами при цьому були і «криві» вимоги псевдонаукових інституцій (міністерств) до самих дисертацій. Хоча причин цьому безліч. Коли якомусь автору відверто графоманських витворів зробиш критичне зауваження, то він огризається в такий спосіб: «Я ж постмодерніст!». Щось подібне можна було почути колись від автора натуралістичних витворів: «Я ж романтик!». Але чомусь ніхто не вигукує, що він лише на половину письменник. Микола Вороний у відомій дискусії з Іваном Франком про нові шляхи розвитку літератури говорив про «цілого» чоловіка. Так само «цілим» має бути й стиль письменника чи метод наукового дослідника. Він дисциплінує художнє та наукове мислення і трохи «розбалансованим» може бути хіба що в перехідні періоди між стилями-епохами: «низове бароко» в час 
наближення літератури до «романтизму», «школярська - бурсацька - гумористика», «бідермаєр» у час між «романтизмом» і «реалізмом», (деякі твори П. Куліша, Ю. Федьковича, російськомовні повісті Т. Шевченка), «натуралізм» у час відмирання «реалізму» і народження «модернізму» (Еміль Золя та твори бориславського циклу Івана Франка), «просвітянська графоманія» 20-х років XX століття (коли в літературу рушив «малописьменний письменник», як казав Петро Панч), а в наші часи - псевдопостмодернізм, за який тримаються малоталановиті від природи літератори. Це, по суті, піна літературного потоку та $є$ надія , що вона невдовзі стече чи лопне, як мильна бульбашка, і ми будемо мати тільки глибоко художні літературні явища. Не виключено, що вони таки твердо приживуться в історії літературного процесу як твори «нового історицизму». Поживемо - побачимо.

\section{Література}

Gazeta «Slovo prosviti», 2019, 4 grudnja.

ŠEVČENKO, Taras: Povne zibrannja tvoriv. U 12 t. T. 2. Kï̈v, 2001.

SUCHOMLINS'KIJ, Vasil': Vibrani tvori v 5-ti tomach. T. 3. Kï̈v,1977.

https://socratify.net/quotes/faust-iogann-volfgang-gete/48074).

https://stosec.com/marcus-fabius-quintilianus.

https://nubip.edu.ua/node/25832).

https://hvylya.net/analytics/zakat-postmodernizma-inflyatsiya-istinyi-krasotyi-i-dobra.html.

prof. Mychajlo Najenko, DrSc.

Director of the Center for Literary Creativity

Institute of Philology

Taras Shevchenko National University of Kyiv, Ukrajina

list2111@gmail.com

This work can be used in accordance with the Creative Commons BY-SA 4.0 International license terms and con ditions (https://creativecommons.org/licenses/by-sa/4.0/legalcode). This does not apply to works or elements (such as image or photographs) that are used in the work under a contractual license or exception or limitation to relevant rights. 